\title{
High-intensity exercise decreases muscle buffer capacity via a decrease in protein buffering in human skeletal muscle
}

\author{
David Bishop \& Johann Edge \& \\ Alberto Mendez-Villanueva \& Claire Thomas \& \\ KnutSchneiker
}

\begin{abstract}
We have previously reported an acute decrease in muscle buffer capacity $\left(\beta m_{\text {in vitro }}\right)$ following high-intensity exercise. The aim of this study was to identify which muscle buffers are affected by acute exercise and the effects of exercise type and a training intervention on these changes. Whole muscle and non-protein $\beta \mathrm{m}_{\text {in }}$ vitro were measured in male endurance athletes $\left(\mathrm{VO}_{2 \max }=59.8 \pm\right.$ $5.8 \mathrm{~mL} \mathrm{~kg}^{-1} \mathrm{~min}^{-1}$ ), and before and after training in male, team-sport athletes $\left(\mathrm{VO}_{2 \max }=55.6 \pm 5.5 \mathrm{~mL} \mathrm{~kg}^{-1} \min ^{-1}\right)$.
\end{abstract}

D. Bishop : J. Edge : K. Schneiker

School of Human Movement and Exercise Science,

The University of Western Australia,

Crawley, WA 6009, Australia

D. Bishop (*)

Facoltà di Scienze Motorie,

Università degli Studi di Verona,

via Casorati 43,

Verona 37131, Italy

e-mail: David.Bishop@univr.it

\section{J. Edge}

Institute of Food, Nutrition and Human Health,

Massey University,

Palmerston North, New Zealand

A. Mendez-Villanueva

ASPIRE, Academy for Sports Excellence,

Doha, Qatar

C. Thomas

Université Montpellier 1,

UFR de Médecine, EA 4202,

34000 Montpellier, France

C. Thomas

UFR Sciences fondamentales et appliquées, Département STAPS,

Université Evry Val d'Essonne,

91000 Evry, France
Biopsies were obtained at rest and immediately after either time-to-fatigue at $120 \% \quad \mathrm{VO}_{2 \max }$ (endurance athletes) or repeated sprints (team-sport athletes). High-intensity exercise was associated with a significant decrease in $\beta \mathrm{m}_{\text {in vitro }}$ in endurance-trained males $\left(146 \pm 9\right.$ to $138 \pm 7 \mathrm{mmol} \mathrm{H}^{+} \cdot \mathrm{kg}$ d.w. $\left.{ }^{-1} \cdot \mathrm{pH}^{-1}\right)$, and in male team-sport athletes both before

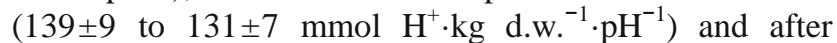
training $\left(152 \pm 11\right.$ to $\left.142 \pm 9 \mathrm{mmol} \mathrm{H^{+ } \cdot \mathrm { kg } \text { d.w. }}{ }^{-1} \cdot \mathrm{pH}^{-1}\right)$. There were no acute changes in non-protein buffering capacity. There was a significant increase in $\beta m_{i n}$ vitro following training, but this did not alter the post-exercise

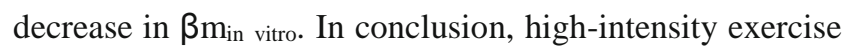
decreased $\beta m_{\text {in }}$ vitro independent of exercise type or an interval-training intervention; this was largely explained by a decrease in protein buffering. These findings have important implications when examining training-induced changes in $\beta m_{i n}$ vitro. Resting and post-exercise muscle samples cannot be used interchangeably to determine

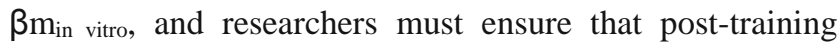
measurements of $\beta \mathrm{m}_{\text {in vitro }}$ are not influenced by an acute decrease caused by the final training bout.

Keywords Buffer Capacity - Lactate transport .

Hydrogen ions · Acidosis · Exercise $\cdot$ Muscle $\cdot$ Activity Fatigue

\section{Introduction}

Intense muscle contractions result in large ionic changes and an increased non-mitochondrial adenosine triphosphate (ATP) turnover, contributing to the accumulation of hydrogen ions $\left(\mathrm{H}^{+}\right)$. While recent findings indicate that the role of $\mathrm{H}^{+}$accumulation during the fatigue process of mammalian muscle fibres may be limited [32], the 
accumulation of $\mathrm{H}^{+}$has been shown to affect oxidative phosphorylation, enzyme activity and ion regulation during some exercise tasks $[15,22,38,40]$. The removal of $\mathrm{H}^{+}$ during intense skeletal muscle contractions occurs via a number of different transport systems and via muscle buffering [4, 23, 24]. Muscle buffer capacity ( $\left.\beta m_{\text {in vitro }}\right)$ is typically estimated by titrating a muscle homogenate with a fixed acid and measures the contribution to physicochemical buffering by protein-bound histidine residues, imidazole-containing dipeptides and phosphates within the muscle but excludes 'dynamic' metabolic buffering such as the rephosphorylation of adenosine diphosphate (ADP) by phosphocreatine ( $\mathrm{PCr}$ ).

It was originally believed that $\beta \mathrm{m}_{\text {in vitro was fixed and }}$ unaffected by acute exercise. However, unaccustomed eccentric exercise has been reported to acutely decrease

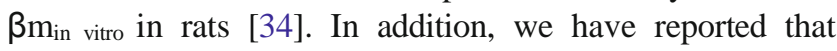
high-intensity exercise is associated with an acute decrease

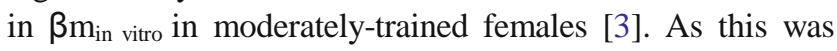
the first study in humans, it is important to verify these results and to determine if this acute decrease in $\beta m_{\text {in vitro }}$ is a common response to different types of high-intensity exercise and to determine whether this response is seen in all subjects (i.e. males and females, the trained and untrained). It is known that metabolic perturbations in response to highintensity exercise differ between males and females [13] and between untrained and trained subjects [18]. Therefore, acute, exercise-induced changes in $\beta m_{\text {in vitro may also differ }}$ in these populations and be influenced by training.

It is also of interest to determine which of the muscle buffers that are measured using the in vitro titration technique (i.e. intramuscular phosphates, protein-bound histidine and dipeptides) are responsible for these acute decreases in

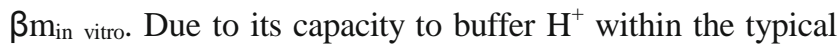
physiological range experienced during high-intensity exercise $(\mathrm{pKa}=6.83)$, carnosine $(N$ - $\beta$-alanyl-L-histidine $)$ is an important muscle buffer, and any loss from the muscle will cause a decrease in $\beta m_{\text {in }}$ vitro. However, using the Hendersson-Hasselbach equation, it can be calculated that our previously reported decrease in $\beta m_{\text {in }}$ vitro [3] would necessitate a loss of $\sim 25 \mathrm{mmol} \cdot \mathrm{kg} \mathrm{d} . \mathrm{w}^{-1}$ of carnosine from the muscle (i.e. an amount greater than that typically reported in muscle $[19,27,31])$. Consistent with this, our subsequent research [12] has indicated that a decrease in muscle carnosine content was not the cause of the decrease

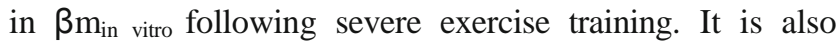
unlikely that the acute decrease in $\beta m_{\text {in vitro }}$ can be attributed to an acute change in muscle phosphate concentration following high-intensity exercise. It has previously been reported that there is no significant decrease in the total adenine nucleotide pool (ATP + ADP + adenosine monophosphate (AMP)) plus inosine 5'-monophosphate (IMP) following a 30-s maximal sprint [39], and no significant change in total muscle phosphate following exercise to exhaustion at $75 \%$ of $\mathrm{VO}_{2 \max }$ [37]. We therefore hypoth-

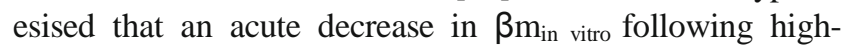
intensity exercise might be related to a decrease in protein buffering.

To date, no previous research has sought to quantify the relative contribution of both non-protein and protein buffering

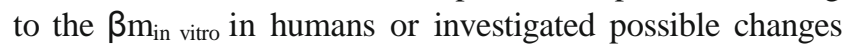
in these components in response to different acute exercise stimuli. The current study therefore had four principal aims. The first was to verify if our previous results (i.e. an acute exercise-induced decrease in $\beta m_{\text {in vitro in women) would }}$ also be observed in men. The second aim was to determine if an acute decrease in $\beta \mathrm{m}_{\text {in }}$ vitro is a common response to different types of high-intensity exercise (i.e. continuous and intermittent). The third aim was to determine if short-term endurance training can confer a protective effect on the acute, exercise-induced decrease in $\beta m_{\text {in vitro. The final aim }}$ was to determine if acute changes in $\beta m_{\text {in }}$ vitro were attributable to acute changes in protein buffering. We hypothesised that decreases in $\beta m_{\text {in }}$ vitro would be the result of acute changes in protein buffering and would not be affected by exercise type or an interval-training program designed to increase $\beta m_{\text {in }}$ vitro.

Materials and methods

\section{Ethical approval}

Subjects were informed of the study requirements, benefits and risks before giving written informed consent. The studies conformed to the latest revision of the Declaration of Helsinki, and approval for the study's procedures was granted by the Research Ethics Committee of the University of Western Australia.

\section{Experimental overview}

In order to perform this study, we recruited six well-trained endurance athletes $\left(\mathrm{VO}_{2 \max }=59.8 \pm 5.8 \mathrm{~mL} \mathrm{~kg}^{-1} \mathrm{~min}^{-1}\right.$; experiment $\mathrm{A}$ ) and six well-trained, male, team-sport athletes $\left(\mathrm{VO}_{2 \max }=55.6 \pm 5.5 \mathrm{~mL} \mathrm{~kg}{ }^{-1} \mathrm{~min}^{-1}\right.$; experiment B). All of the subjects first completed a familiarisation trial of the graded exercise test (GXT) and their respective highintensity exercise test. During the subsequent main trials, each subject had a muscle biopsy from the vastus lateralis muscle at rest and immediately upon cessation of the highintensity exercise test. Subjects in experiment B (who also performed 5 weeks of training) had their pre- and posttraining tests conducted at the same time of day. Subjects were required to consume no food or beverages (other than water) $2 \mathrm{~h}$ prior to testing and were asked not to consume 
alcohol or caffeine or to perform vigorous exercise in the $24 \mathrm{~h}$ prior to testing.

\section{Graded exercise test}

The GXTs were performed on an air-braked, track-cycle ergometer (Evolution Pty. Ltd., Adelaide, Australia; experiment A) or a motorised treadmill (Human Movement, Perth, Australia; experiment B) and consisted of graded exercise steps using an intermittent protocol (1-min break between stages). The tests commenced at $60 \mathrm{~W}$ or $8.5 \mathrm{~km} \cdot \mathrm{h}^{-1}$ (for experiments $\mathrm{A}$ and $\mathrm{B}$, respectively) and thereafter, intensity was increased by $40 \mathrm{~W}$ or $1.5 \mathrm{~km} \cdot \mathrm{h}^{-1}$ (for experiments A and B, respectively) every 3 min until volitional exhaustion.

\section{Gas analysis during the GXT}

During the GXT, expired air was continuously analysed for $\mathrm{O}_{2}$ and $\mathrm{CO}_{2}$ concentrations using Ametek gas analysers (Applied Electrochemistry, SOV S-3A11 and COV CD-3A, Pittsburgh, PA, USA). Ventilation was recorded every $15 \mathrm{~s}$ using a turbine ventilometer (Morgan, 225A, Kent, England). The gas analysers were calibrated immediately before and verified after each test using three certified gravimetric gas mixtures (BOC Gases, Chatswood, Australia); the ventilometer was calibrated pre-exercise and verified post-exercise using a 11 syringe in accordance with the manufacturer's instructions. The ventilometer and gas analysers were connected to an IBM PC which measured and displayed variables every $15 \mathrm{~s}$. The sum of the two highest consecutive 15-s values was recorded as the subject's $\mathrm{VO}_{2 \max }$.

\section{High-intensity exercise}

To determine if an acute decrease in $\beta \mathrm{m}_{\text {in vitro is a common }}$ response to different types of high-intensity exercise, we performed two experiments-each with a different type of high-intensity exercise. These high-intensity exercise tests consisted of time to fatigue at $120 \%$ of the power output recorded at $\mathrm{VO}_{2 \max }(124 \pm 20 \mathrm{~s}$; experiment $\mathrm{A})$ or a repeatedsprint test $(6 \times$ all-out 4 -s sprints separated by $21 \mathrm{~s}$ of recovery; experiment B). All high-intensity exercise tests were performed on an air-braked, front-access cycle ergometer (Model Ex-10, Repco, Australia). Toe clips and heel straps were used to secure the feet to the pedals, and the test was performed in the seated position. Strong verbal encouragement was provided to each subject during the test.

\section{Training intervention (experiment B)}

Within 4-7 days of baseline testing, all subjects in experiment B started an interval-training program similar to that which had previously been reported to significantly increased $\beta \mathrm{m}_{\text {in }}$ vitro $[10,11]$. Subjects completed five to eight 2-min running intervals on an outdoor grass track at an initial intensity of $\sim 100 \%$ of the velocity recorded at $\mathrm{VO}_{2 \max }$. Each 2-min interval was interspersed with a 2-min passive recovery period. Three training sessions were performed per week (Monday, Wednesday, Friday) for five consecutive weeks, and training followed a periodised and progressive plan. All training was preceded by a 10-min standardised warm up involving general aerobic and dynamic stretching components.

Muscle sampling and analysis

On the day of the performance test, incisions were made under local anaesthesia ( $5 \mathrm{~mL}, 1 \%$ Xylocaine) into the vastus lateralis of each subject (mid-way between the anterior, superior iliac spine and the patella). The first muscle sample was taken (prior to warm-up) during supine rest. The second muscle sample was taken immediately (within $10 \mathrm{~s}$ ) following the cessation of the respective performance test, while the subject remained on the cycle ergometer. The samples were then removed from the biopsy needle and immediately stored at $-80^{\circ} \mathrm{C}$ until subsequent analysis.

Muscle buffering capacity; titration method ( $\beta m_{\text {in }}$ vitro $)$ and $\left[\mathrm{H}^{+}\right]$

Freeze-dried muscle samples (1.8-2.5 mg d.w.) were dissected free from visible blood, fat and connective tissue and then homogenised on ice for $2 \mathrm{~min}$ in a solution containing sodium fluoride $(\mathrm{NaF} ; 10 \mathrm{mM})$ at a dilution of $30 \mathrm{mg}$ dry muscle $\cdot \mathrm{mL}^{-1}$ of homogenising solution [28]. Freeze-dried muscle samples (1.8-2.5 mg) were also deproteinised with the addition of $3 \%$ solid sulfosalicylic acid and centrifuged at $1,000 \times g$ for $10 \mathrm{~min}$ [31]. Deproteinisation does not alter the effectiveness of non-protein buffers in vitro [7]. Measurements of $\mathrm{pH}$ for both the whole-muscle and deproteinised muscle samples were then made at $37^{\circ} \mathrm{C}$ with a microelectrode (MI-415, Microelectrodes, Bedford, NH, USA) connected to a $\mathrm{pH}$ meter (SA 520, Orion Research, Cambridge, MA, USA). After initial $\mathrm{pH}$ measurement, muscle homogenates for both preand post-exercise samples (both the whole-muscle and deproteinised muscle samples) were adjusted to a $\mathrm{pH}$ of $\sim 7.2$ with a sodium hydroxide $(\mathrm{NaOH})$ solution and then titrated to a $\mathrm{pH}$ of $\sim 6.2$ by the serial addition of $2 \mu \mathrm{L}$ of hydrochloric acid $(\mathrm{HCl} ; 10 \mathrm{mM})$. From the fitted titration trendline, the number of moles of $\mathrm{H}^{+}$(per kilogram of dry muscle) required to change the $\mathrm{pH}$ from 7.1 to 6.5 was interpolated (mmol H $\mathrm{H}^{+} \cdot \mathrm{kg}$ muscle d.w. ${ }^{-1} \cdot 0.6 \mathrm{pH}^{-1}$ ). This value was also normalised to the whole $\mathrm{pH}$ unit for final 
display as millimoles $\mathrm{H}^{+}$per kilogram dry muscle per unit $\mathrm{pH}\left(\mathrm{mmol} \mathrm{H} \mathrm{H}^{+} \cdot \mathrm{kg}\right.$ muscle $\mathrm{d} . \mathrm{w}^{-1} \cdot \mathrm{pH}^{-1}$ ) and determined as the subject's $\beta m_{\text {in vitro. The protein buffer capacity was }}$ estimated by subtracting the deproteinised $\beta m_{\text {in vitro from }}$ the whole-muscle $\beta m_{\text {in }}$ vitro.

\section{Statistical analysis}

All values are reported as mean $\pm \mathrm{SD}$. For experiment $\mathrm{A}$, one-way analysis of variance (ANOVA) with repeated measures for time was used to test for main effects. For experiment B, two-way ANOVA with repeated measures for time was used. Least-squares linear regression analysis was used to calculate correlation coefficients between resting values and acute changes in $\beta m_{\text {in }}$ vitro, using Pearson's product moment $(r)$. Significance was accepted at $P<0.05$.

\section{Results}

\section{Experiment A}

Exercise to task failure at $120 \%$ of the power output recorded at $\mathrm{VO}_{2 \max }$ resulted in a significant decrease in muscle $\mathrm{pH}$ from $7.00 \pm 0.05$ to $6.61 \pm 0.06$. This was associated with a significant decrease in whole-muscle $\beta m_{\text {in vitro }}(146 \pm 9$ to $138 \pm 6.8 \mathrm{mmol} \mathrm{H}^{+} \cdot \mathrm{kg} \mathrm{d.w}{ }^{-1} \cdot \mathrm{pH}^{-1} ; P<0.05$, Fig. 1a) and no significant change in deproteinised $\beta m_{\text {in }}$ vitro $(95 \pm 4$ to $\left.94 \pm 4 \mathrm{mmol} \mathrm{H} \cdot \mathrm{kg} \mathrm{d} . \mathrm{w}^{-1} \cdot \mathrm{pH}^{-1} ; P<0.05\right)$. Thus, it can be calculated that there was a significant decrease in protein $\beta \mathrm{m}_{\text {in }}$ vitro $\left(51 \pm 8\right.$ to $44 \pm 6 \mathrm{mmol} \mathrm{H}^{+} \cdot \mathrm{kg}$ d.w. ${ }^{-1} \cdot \mathrm{pH}^{-1}$; $P<0.05$, Fig. 1b). Significant correlations were observed between initial $\beta m_{\text {in }}$ vitro and the decrease in $\beta m_{\text {in }}$ vitro following exercise for both whole-muscle ( $r=0.75, P<0.05$, $n=6)$ and protein $(r=0.93, P<0.05, n=6)$ values.

\section{Experiment B}

The repeated-sprint task ( $6 \times$ all-out 4 -s sprints separated by $21 \mathrm{~s}$ of recovery) resulted in a significant decrease in muscle $\mathrm{pH}$ from $6.98 \pm 0.05$ to $6.79 \pm 0.07$ pre-training and $6.99 \pm 0.04$ to $6.77 \pm 0.08$ post-training. This task was associated with a significant decrease in whole-muscle $\beta \mathrm{m}_{\text {in }}$ vitro both before $\left(139 \pm 9\right.$ to $131 \pm 7 \mathrm{mmol} \mathrm{H}^{+} \cdot \mathrm{kg}$ d.w. ${ }^{-1} \cdot \mathrm{pH}^{-1} ; P<0.05$, Fig. $\left.2 \mathrm{a}\right)$ and after training $(152 \pm 11$ to $142 \pm 9 \mathrm{mmol} \mathrm{H} \cdot \mathrm{kg} \mathrm{d.w}{ }^{-1} \cdot \mathrm{pH}^{-1} ; P<0.05$, Fig. 2b). The decrease in $\beta m_{\text {in }}$ vitro was almost completely attributed to a significant decrease in estimated protein buffering both before $\left(52 \pm 8\right.$ to $\left.45 \pm 7 \mathrm{mmol} \mathrm{H} \cdot \mathrm{kg} \mathrm{d}^{+} \mathrm{w}^{-1} \cdot \mathrm{pH}^{-1} ; P<0.05\right)$ and after training $\left(56 \pm 8\right.$ to $47 \pm 7 \mathrm{mmol} \mathrm{H^{+ }} \cdot \mathrm{kg} \mathrm{d}_{\mathrm{w}}{ }^{-1} \cdot \mathrm{pH}^{-1}$; $P<0.05)$. A significant correlation was observed between initial protein $\beta m_{i n}$ vitro and the decrease in protein
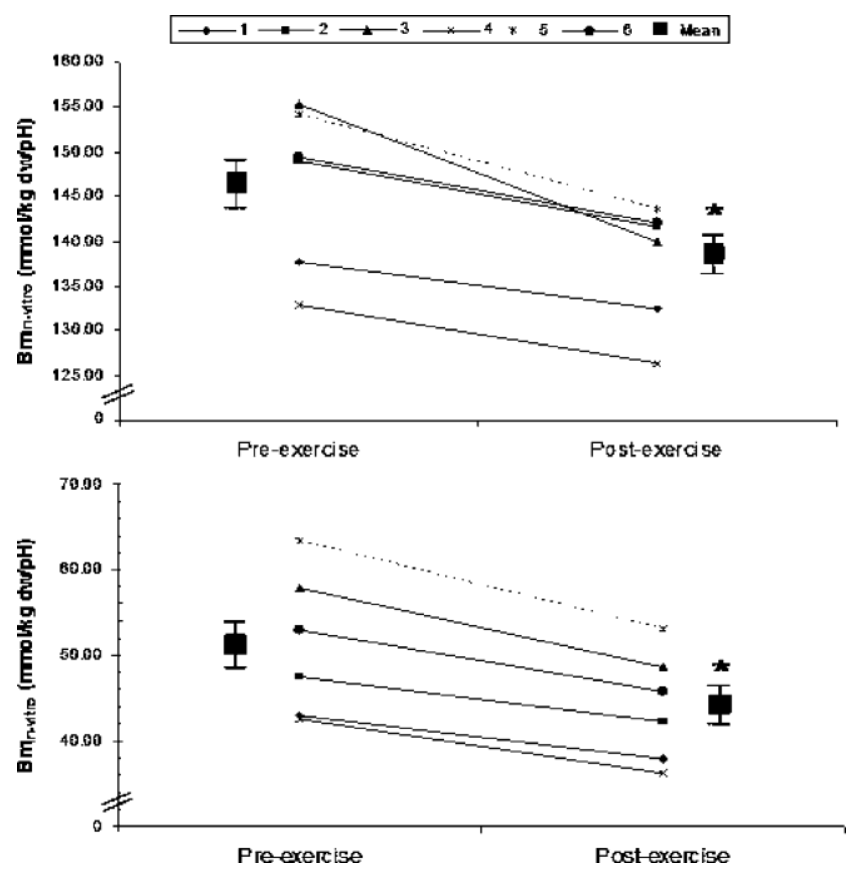

Fig. 1 Individual changes in titrated muscle buffer capacity $\left(\beta m_{\text {in }}\right.$ vitro; mmol $\mathrm{H}^{+} \cdot \mathrm{kg}$ muscle d.w. ${ }^{-1} \cdot \mathrm{pH}^{-1}$ ) for whole muscle (a) and muscle protein (b) pre- and immediately post-exercise to fatigue at $120 \%$ of $\mathrm{VO}_{2 \max }$. Also plotted are the mean values. $* P<0.05$, postexercise mean significantly different from pre-exercise mean

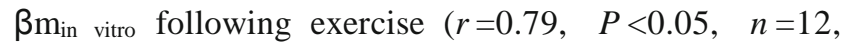
Fig. 3). There were significant increases in $\beta m_{\text {in }}$ vitro, deproteinised $\beta \mathrm{m}_{\mathrm{in}}$ vitro $\left(87 \pm 8\right.$ to $96 \pm 10 \mathrm{mmol} \mathrm{H}^{+} \cdot \mathrm{kg}$ d.w. $\left.{ }^{-1} \cdot \mathrm{pH}^{-1} ; \quad P<0.05\right)$ and estimated protein $\beta \mathrm{m}_{\text {in }}$ vitro

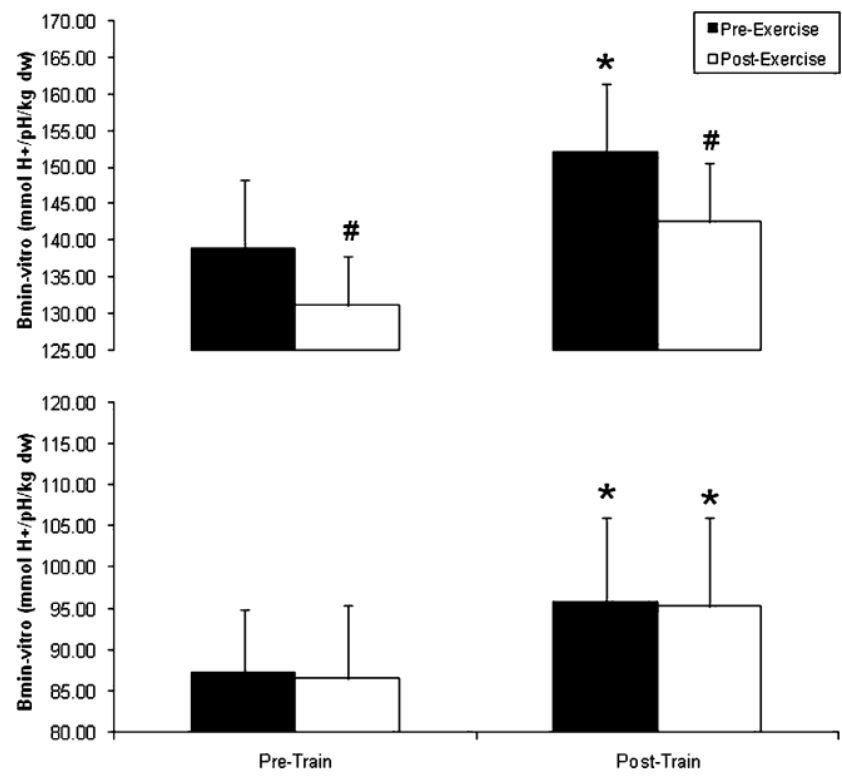

Fig. 2 Changes in_fitrated muscle buffer capacity $\left(\beta \mathrm{m}_{\text {in vitro }}\right.$; mol $\mathrm{H} \cdot \mathrm{kg}$ muscle d.w. $\cdot \mathrm{pH}$ ) for whole muscle (a) and deproteinised muscle (b) before and after 6 weeks of high-intensity interval training. ${ }^{*} P<0.05$, significant increase following training. \# $P<0.05$, postexercise mean significantly different from pre-exercise mean 


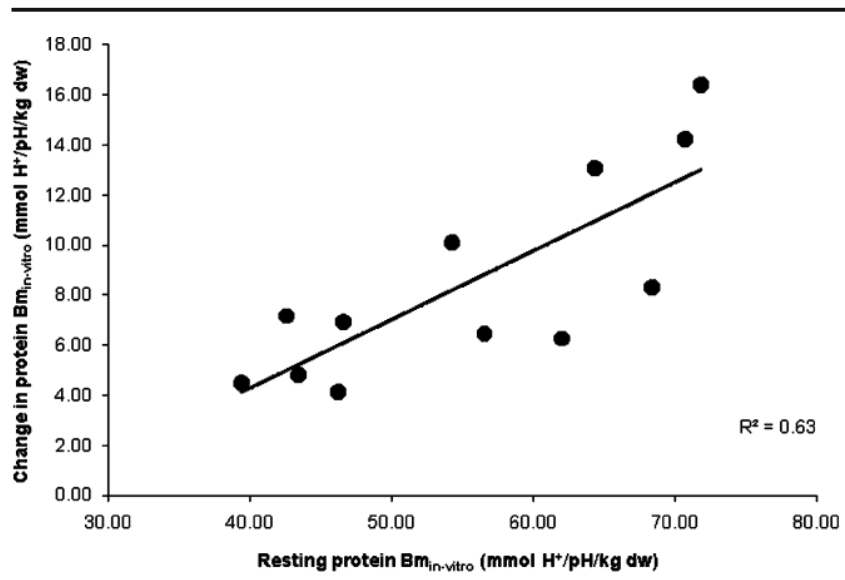

Fig. 3 Relationship between resting protein $\beta m_{\text {in vitro }}$ and change in protein $\beta \mathrm{m}_{\text {in vitro }}$ following the repeated-sprint test in well-trained, team-sport athletes (experiment B). Data include the pre- and posttraining data for six subjects (i.e. $n=12$ )

(52 \pm 8 to $56 \pm 8 \mathrm{mmol} \mathrm{H} \cdot \mathrm{kg} \mathrm{d.w} .^{-1} \cdot \mathrm{pH}^{-1} ; P<0.05$ ) following training.

\section{Discussion}

This is the first human study to report $\beta m_{\text {in }}$ vitro values for both whole and deproteinised human vastus lateralis muscle pre- and post-exercise. The main finding was that different types of high-intensity exercise were associated with a

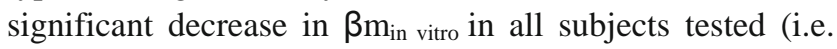
male endurance and team-sport athletes) and for both exercise tasks (i.e. continuous and repeated-sprint exercise). There were no acute changes in the non-protein buffering capacity which suggests that acute decreases in $\beta m_{i n}$ vitro were due to an acute decrease in the buffering by proteins. There were strong negative correlations between the resting protein buffer capacity and the decrease in protein buffer capacity following high-intensity exercise $(r=0.79-0.93$; $P<0.05)$. Consistent with this result, the significant increase in resting protein buffer capacity following interval training was associated with a trend for a greater acute decrease in protein buffer capacity post-training, but this did not reach statistical significance.

$\beta \mathrm{m}_{\text {in vitro }}$

The titration method measures the contribution to physicochemical buffering by proteins, dipeptides and phosphates but excludes 'dynamic buffering' (e.g. the rephosphorylation of $\mathrm{ADP}$ by $\mathrm{PCr}$ ) and the bicarbonate contribution (as $\mathrm{CO}_{2}$ evaporates during the freeze-drying) [19]. It is also important to note that homogenisation, particularly on subsequent incubation at $37^{\circ} \mathrm{C}$, increases the quantity of inorganic phosphate $\left(\mathrm{P}_{\mathrm{i}}\right.$; and probably also hexose monophosphates; [29]) available to contribute to in vitro physicochemical buffering, with respect to in vivo. This is because the release of previously sequestered calcium triggers an acceleration of ATP turnover [35] which, coupled to the utilisation of anaerobic metabolism, results in almost complete $(>95 \%)$ degradation of PCr and ATP [29]. Thus, muscle buffer capacity determined by the homogenate technique will differ slightly from intact preparations.

Surprisingly, no previous research has sought to quantify the relative contribution of both non-protein and

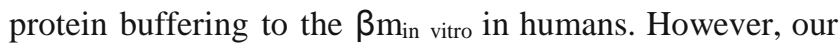

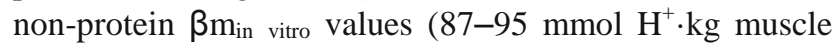
d.w. ${ }^{-1} \cdot \mathrm{pH}^{-1}$ or $60-65 \%$ of the whole-muscle $\beta m_{\text {in vitro }}$ ) are very similar to the results reported for marathon runners ( 90 mmol $\mathrm{H}^{+} \cdot \mathrm{kg}$ muscle d.w. ${ }^{-1} \cdot \mathrm{pH}^{-1}$; [31]). Similarly, another study has estimated that $60-70 \%$ of nonbicarbonate buffering in mammalian skeletal muscle is due to non-protein substances [1]. From our results, we can calculate that the protein buffering capacity was $\sim 52 \mathrm{mmol}$ $\mathrm{H}^{+} \cdot \mathrm{kg}$ muscle d.w. ${ }^{-1} \cdot \mathrm{pH}^{-1}(30-35 \%)$ for both male triathletes and male team-sport athletes in the present study. This

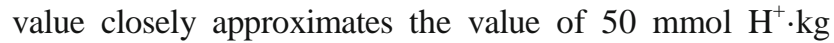
muscle d.w. ${ }^{-1} \cdot \mathrm{pH}^{-1}$ that can be calculated from the reported histidine concentration in human muscle protein $(2.7 \mathrm{~g} / 100 \mathrm{~g}$ of protein; [16]), the protein content in muscle tissue ( 170 g.kg w.w. ${ }^{-1}$; [17]) and the pKa value of the imidazole ring in protein-bound histidine residues (6.25; [42]). These calculations however, must be treated with caution as theoretical calculations of the buffering power of proteinbound histidine residues are complicated by uncertainty regarding the $\mathrm{pKa}$ value of histidine $\left(5.97\right.$ at $\left.37^{\circ} \mathrm{C}\right)$ when incorporated into proteins [6]. Nonetheless, our results are consistent with values that can be estimated from previous research and confirm that proteins are an important buffer within human skeletal muscle.

Acute decreases in $\beta m_{\text {in vitro }}$

Consistent with previous research [3, 20], we observed a significant decrease in $\beta \mathrm{m}_{\text {in }}$ vitro following an acute bout of high-intensity exercise. As previously reported in women, this acute decrease in $\beta m_{\text {in }}$ vitro was observed in all subjects (Fig. 1). Furthermore, this acute decrease occurred following both constant-intensity and repeated-sprint exercise. Interestingly, this acute decrease was positively related to the resting

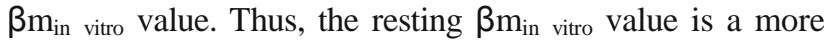
important determinant of the subsequent decrease in

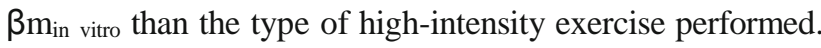

Although an acute decrease in $\beta \mathrm{m}_{\text {in }}$ vitro has previously been observed [3], we report for the first time that this appears to be predominately due to a decrease in protein buffering. In both experiments $\mathrm{A}$ and $\mathrm{B}$, acute, highintensity exercise resulted in no significant change in the non-protein buffer capacity (i.e. the buffering by intramus- 
cular phosphates and carnosine). This is consistent with previous research which has not observed changes in the total adenine nucleotide pool (ATP+ ADP +AMP+ IMP) [39] or total muscle phosphate [37] following high-intensity exercise. While one study has reported that acute, intense exercise results in a $10 \%$ loss of carnosine from the muscle [9], using a pKa of 6.83 [26] and a typical resting muscle carnosine concentration of $20 \mathrm{mmol} \mathrm{kg}$ muscle d.w. ${ }^{-1}$ [19, $27,31]$, it can be calculated that this would at most

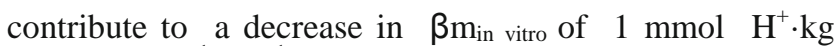
muscle d.w. ${ }^{-1} \cdot \mathrm{pH}^{-1}$. The unchanged non-protein buffer capacity also argues against the possibility that the decrease

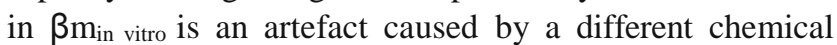
composition of the pre- and post-exercise muscle samples (e.g., differences in the quantity of $\mathrm{P}_{\mathrm{i}}$ and hexose monophosphates will affect the non-protein and whole-muscle buffer capacity due to differences in their respective $\mathrm{pKa}$ ). Thus, these previous findings are consistent with our observation that a decrease in protein buffering is predominately responsible for the acute decreases in $\beta m_{\text {in }}$ vitro observed following high-intensity exercise.

As histidine is the only amino acid able to exert a buffering function in the intracellular $\mathrm{pH}$ range [21], our results therefore suggest that there was an acute, exerciseinduced decrease in the buffering by protein-bound histidine. Such changes could potentially be brought about by a loss of protein from the muscle, the release of histidine bound to protein and/or chemical changes in the imidazole ring belonging to histidine (and subsequent decreases in the apparent $\mathrm{pKa}$ ). Using the Hendersen-Hasselbach equation, it can be calculated that the decrease in protein buffering observed in the present study ( 7-9 $\mathrm{mmol} \mathrm{H}^{+} \cdot \mathrm{kg}$ muscle d.w. ${ }^{-1} \cdot \mathrm{pH}^{-1}$ ) would require the loss of $\sim 15 \%$ of intracellular protein. While exhaustive endurance exercise in rats has been reported to be associated with a $13 \%$ loss of protein from muscle [8], it seems unlikely that such changes would have occurred within the time frame observed in our study (<3 min). Nonetheless, it is possible that smaller losses of protein did contribute to our observed acute decrease in protein buffering, and studies investigating the acute loss of protein during brief, high-intensity exercise $(>100 \%$ $\mathrm{VO}_{2 \max }$ ) are warranted.

While we are unaware of any previous research that has investigated changes in muscle histidine following brief, intense exercise, it also seems unlikely that the release of histidine bound to protein can completely account for our findings. Only slight increases in histidine concentration (5-10\%) have been reported following $1 \mathrm{~h}$ of exercise at approximately $70 \%$ of $\mathrm{VO}_{2 \max }$ [5]. Furthermore, much larger increases following brief, high-intensity exercise are improbable as reported changes in other muscle amino acids (e.g., alanine) are similar following either $4 \mathrm{~min}$ of exercise at $100 \%$ of $\mathrm{VO}_{2 \max }$ [25] or $1 \mathrm{~h}$ of exercise at $70 \%$ of $\mathrm{VO}_{2 \max }$ [5]. It should be noted however, that the release of histidine bound to protein is not necessary to explain our observations and that exercise-induced changes in the imidazole ring belonging to histidine (and a subsequent decrease in the apparent $\mathrm{pKa}$ ) may also contribute to the acute decrease in protein buffering observed in this study. While we are unaware of research investigating exerciseinduced changes in the apparent $\mathrm{pKa}$ of histidine, only a very small decrease in $\mathrm{pKa}(<0.15)$ would be required to explain our results. Furthermore, rather than being attributable to one cause, acute changes in protein buffer capacity may be due to small contributions from all three of the above hypothesised mechanisms (i.e. the loss of protein from the muscle, the release of histidine bound to protein and/or chemical changes in the imidazole ring belonging to histidine).

\section{Training and $\beta m_{\text {in vitro }}$}

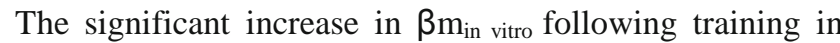
experiment $\mathrm{B}$ is consistent with the majority of training studies that have used high-intensity intervals interspersed with relatively short rest periods (work to rest ratio $\geq 1: 1$ ) [2, $10,11]$. While the changes observed in this study are not as large as those reported in some studies, this can probably be attributed to the relatively high starting levels of our subjects and the previous observation that there is a negative relationship between starting values and traininginduced changes in $\beta m_{\text {in vitro }}$ [10]. A novel observation of the present study, however, is that the increase in $\beta m_{\text {in vitro }}$ was due to an increase in both protein and non-protein buffering. As intracellular phosphate concentration has not typically been reported to change in response to training [18], an increase in non-protein buffering is likely to be explained by the previous observation that high-intensity training is associated with an increase in carnosine [41]. While it has been suggested that increased $\beta m_{\text {in }}$ vitro following training can largely be attributed to changes in carnosine concentration [30], our results suggest that changes in protein are also important. This is consistent with previous reports of increases in protein concentration with training [33] and the observation that protein concentration is higher in trained sportsmen when compared with sedentary controls [36].

A final observation in the present study was that training did not significantly alter the acute decrease in $\beta m_{\text {in vitro }}$ following high-intensity exercise (experiment B), although there was a trend for a greater decrease following training. This can probably be related to the finding that the decrease in protein buffer capacity during intense exercise was correlated with the resting protein buffer capacity (Fig. 3). Interestingly, training has also been reported not to protect against the acute decrease in lactate transport induced by exhaustive exercise [14]. 
Summary

In conclusion, the results of this study confirm that proteins are an important buffer within skeletal muscle. More importantly, it appears that it is a decrease in this protein buffering that is responsible for the acute decrease in $\beta m_{\text {in vitro }}$ in response to high-intensity exercise. Further research is required to determine the relative contributions of a loss of protein from the muscle, the release of histidine bound to protein and/or chemical changes in the imidazole ring belonging to histidine to this acute decrease in protein buffering capacity. These findings have important implications for study design when examining training-induced changes in $\beta \mathrm{m}_{\text {in }}$ vitro. Resting and post-exercise muscle samples cannot be used interchangeably to determine $\beta m_{\text {in vitro }}$, and researchers must try to exclude the possibility that reported training-induced changes in $\beta \mathrm{m}_{\text {in vitro }}$ are not influenced by the acute effects of the last training bout. Future studies should verify these findings and also examine the time course of the acute changes that we have reported.

\section{References}

1. Bate Smith EC (1938) The buffering of muscle in rigor; protein, phosphate and carnosine. J Physiol 92:336-343

2. Bell GJ, Wenger A (1988) The effect of one-legged sprint training on intramuscular $\mathrm{pH}$ and nonbicarbonate buffering capacity. Eur J Appl Physiol 58:158-164

3. Bishop D, Edge J, Thomas C, Mercier J (2007) High-intensity exercise acutely decreases the membrane content of MCT1 and MCT4 and buffer capacity in human skeletal muscle. J Appl Physiol 102:616-621

4. Bishop D, Edge J, Thomas C, Mercier J (2008) Effects of highintensity training on muscle lactate transporters and postexercise recovery of muscle lactate and hydrogen ions in women. Am J Physiol Regul Integr Comp Physiol 295:R1991-R1998

5. Blomstrand E, Saltin B (1999) Effect of muscle glycogen on glucose, lactate and amino acid metabolism during exercise and recovery in human subjects. J Physiol 514:293-302

6. Christensen H (1966) Protein as buffers. Ann N Y Acad Sci $133: 34-40$

7. Davey C (1960) The significance of carnosine and anserine in striated skeletal muscles. Arch Biochem Biophysiol 89:296-302

8. Dohm GL, Puente F, Smith C, Edge A (1978) Changes in tissue protein levels as a result of endurance exercise. Life Sci 23:845-850

9. Dupin A, Stvolinski S (1986) Changes in carnosine levels in muscles working in different regimens of stimulation. Biokhimiia 51:160-164

10. Edge J, Bishop D, Goodman C (2006) Effects of chronic $\mathrm{NaHCO} 3$ ingestion during interval training on changes to muscle buffer capacity, metabolism, and short-term endurance performance. J Appl Physiol 101:918-925

11. Edge J, Bishop D, Goodman C (2006) The effects of training intensity on muscle buffer capacity in females. Eur J Appl Physiol 96:97-105

12. Edge J, Goodman C, Bishop D (2006) Very high-intensity interval training with short rest periods decreases muscle buffer capacity. ECSS Conference, Laussane:477
13. Esbjornsson-Liljedahl M, Sundberg CJ, Norman B, Jansson E (1999) Metabolic response in type I and type II muscle fibers during a 30-s cycle sprint in men and women. J Appl Physiol 87 (4):1326-1332

14. Eydoux N, Py G, Lambert K, Dubouchaud H, Prefaut C, Mercier J (2000) Training does not protect against exhaustive exerciseinduced lactate transport capacity alterations. Am J Physiol Endocrinol Metab 278:E1045-E1052

15. Favero TG, Zable AC, Bowman MB, Thompson A, Abramson JJ (1995) Metabolic end products inhibit sarcoplasmic reticulum Ca2 +release and [3H]ryanodine binding. J Appl Physiol 78:1665-1672

16. Furst P, Jonsson A, Josephson B, Vinnars E (1970) Distribution in muscle and liver vein protein of $15 \mathrm{~N}$ administered as ammonium acetate to man. J Appl Physiol 29:307-312

17. Gore CJ, Hahn AG, Aughey RJ, Martin DT, Ashenden MJ, Clark SA, Garnham AP, Roberts AD, Slater GJ, McKenna MJ (2001) Live high:train low increases muscle buffer capacity and submaximal cycling efficiency. Acta Physiol Scand 173:275-286

18. Harmer AR, McKenna MJ, Sutton JR, Snow RJ, Ruell PA, Booth J, Thompson MW, Mackay NA, Stathis CG, Crameri RM, Carey MF, Eager DM (2000) Skeletal muscle metabolic and ionic adaptations during intense exercise following sprint training in humans. J Appl Physiol 89:1793-1803

19. Harris RC, Marlin DJ, Dunnett M, Snow DH, Hultman E (1990) Muscle buffering capacity and dipeptide content in the thoroughbred horse, greyhound dog and man. Comp Biochem Physiol 97A:249-251

20. Hultman E, Del Canale S, Sjoholm H (1985) Effect of induced metabolic acidosis on intracellular $\mathrm{pH}$, buffer capacity and contraction force of human skeletal muscle. Clin Sci 69:505-510

21. Hultman E, Sahlin K (1980) Acid-base balance during exercise. Exerc Sport Sci Rev 8:41-128

22. Jubrias SA, Crowther GJ, Shankland EG, Gronka RK, Conley KE (2003) Acidosis inhibits oxidative phosphorylation in contracting human skeletal muscle in vivo. J Physiol 533:589-599

23. Juel C (1997) Lactate-proton cotransport in skeletal muscle. Physiol Rev 77:321-358

24. Juel C (1998) Muscle $\mathrm{pH}$ regulation: role of training. Acta Physiol Scand 162:359-366

25. Katz A, Broberg S, Sahlin K, Wahren J (1986) Muscle ammonia and amino acid metabolism during dynamic exercise in man. Clin Physiol 6:365-379

26. Lenz G, Martell A (1968) Metal complexes of carnosine. Biochemistry 3:750-753

27. Mannion AF, Jakeman PM, Dunnett M, Harris RC, Willan PL (1992) Carnosine and anserine concentrations in the quadriceps femoris muscle of healthy humans. Eur J Appl Physiol Occup Physiol 64:47-50

28. Mannion AF, Jakeman PM, Willan PLT (1993) Determination of human skeletal muscle buffer value by homogenate technique: methods of measurement. J Appl Physiol 75(3):1412-1418

29. Marlin DJ, Harris RC (1991) Titrimetric determination of muscle buffering capacity in biopsy samples. Equine Vet J 23:193-197

30. Parkhouse WS, McKenzie DC (1984) Possible contribution of skeletal muscle buffers to enhanced anaerobic performance; a brief review. Med Sci Sports Exerc 16:328-338

31. Parkhouse WS, McKenzie DC, Hochachka PW, Ovalle WK (1985) Buffering capacity of deproteinized human vastus lateralis muscle. J Appl Physiol 58(1):14-17

32. Pedersen TH, Nielsen OB, Lamb GD, Stephenson DG (2004) Intracellular acidosis enhances the excitability of working muscle. [see comment]. Science 305:1144-1147

33. Penman KA (1969) Ultrastructural changes in human striated muscle using three methods of training. Res Q 10:722-746

34. Pilegaard H, Asp S (1998) Effect of prior eccentric contractions on lactate/H+ transport in rat skeletal muscle. Am J Physiol Endocrinol Metab 274:E554-E559 
35. Portner H, Boutilier R, Tang Y, Toews D (1990) Determination of intracellular $\mathrm{pH}$ and $\mathrm{PCO} 2$ after metabolic inhibition by fluoride and nitilotriacetic acid. Respir Physiol 81:255-274

36. Sahlin K, Henriksson J (1984) Buffer capacity and lactate accumulation in skeletal muscle of trained and untrained men. Acta Physiol Scand 122:331-339

37. Sahlin K, Soderlund K, Tonkonogi M, Hirakoba K (1997) Phosphocreatine content in single fibers of human muscle after sustained submaximal exercise. Am J Physiol Cell Physiol 273: C172-C178

38. Spriet LL, Lindinger MI, McKelvie RS, Heigenhauser GJF, Jones NL (1989) Muscle glycogenolysis and $\mathrm{H}^{+}$concentration during maximal intermittent cycling. J Appl Physiol 66:8-13
39. Stathis CG, Febbraio MA, Carey MF, Snow RJ (1994) Influence of sprint training on human skeletal muscle purine nucleotide metabolism. J Appl Physiol 76(4):1802-1809

40. Street D, Nielsen JJ, Bangsbo J, Juel C (2005) Metabolic alkalosis reduces exercise-induced acidosis and potassium accumulation in human skeletal muscle interstitium. J Physiol 566:481-489

41. Suzuki Y, Ito O, Takahashi H, Takamatsu K (2004) The effect of sprint training on skeletal muscle carnosine in humans. Int J Sport Health Sci 2:105-110

42. Wayslishen R, Tomlinson G (1975) $\mathrm{pH}$-dependence of $13 \mathrm{C}$ chemical shifts and 13C, $\mathrm{H}$ coupling constants in imadozole and L-histidine. Biochem J 147:605-607 